\title{
Çevirilerin resmi olarak onaylanması: Ülkemizde yeminli tercümanlık müessesesi ve dünyadaki yeminli/tasdikli çeviri uygulamaları üzerine genel bir değerlendirme
}

Nazan Müge UYSAL ${ }^{1}$

\begin{abstract}
APA: Uysal, N. M. (2020). Çevirilerin resmi olarak onaylanması: Ülkemizde yeminli tercümanlık müessesesi ve dünyadaki yeminli/tasdikli çeviri uygulamaları üzerine genel bir değerlendirme. RumeliDE Dil ve Edebiyat Araştırmaları Dergisi, (18), 709-724. DOI: 10.2900o/rumelide.706503
\end{abstract}

\section{$\ddot{O} \mathbf{z}$}

Çevirisi yapılan bir belgenin doğruluğunun, gerçekliğinin ve güvenilirliğinin tasdik edilmesinin gerekli olduğu durumlarda, çeviriye resmiyet kazandırılması gerekir. Çevirilerin resmi olarak onaylanması, "yeminli/tasdikli çeviri” olarak adlandırılan çeviri alanını oluşturur. "Yeminli/tasdikli çeviri” iki temel kavramı barındırır: Bir evrakı doğru, gerçek ve güvenilir bir biçimde çevirebilecek olan çevirmenlerin belirlenmesi ve bu çevirmenleri belirlemek üzere yetkilendirilen mercii. Dünyanın farklı ülkelerinde, ülkelerin adalet sistemlerindeki işleyiş ve düzenlemelere bağlı olarak, çevirilere resmiyet kazandırılmasına yönelik çeşitli uygulamalar yer alır. Genellikle yeminli/tasdikli çeviri yapacak çevirmenler bir devlet kurumu veya bir çevirmen meslek örgütü tarafından belirlenir ve temel değerlendirme ölçütü yaygın olarak adayın çeviri ve dil becerisini ölçen bir sınavdır. Ülkemizde ise yeminli çevirmenler Noterlik Kanunu Yönetmeliği'nin ilgili maddesi uyarınca noterlerin yemin zaptı düzenlemesi ile yetkilendirilir. Ancak çevirinin resmiyet kazanması için yeminli çevirmenin tasdiki yeterli olmayabilir, genellikle evrakın noter tarafından da onaylanması gerekmektedir. Yeminli çevirmenlerin noterlik dairelerinde çalıştığı 1970’li yıllardaki çeviri faaliyetlerine göre düzenlenen bu yönetmeliğin bugünün değişen koşullarında halen uygulanıyor olması hem yeminli çeviri alanında çalışan çevirmenler hem de çevirmenlik mesleği açısından olumsuz bir tablo oluşturmaktadır. Bu çalışma, ülkemizdeki noter-yeminli çeviri/çevirmen ilişkisine tarihsel bir perspektiften bakarak günümüzde noterlerin yeminli çeviri alanında yetkilendirme mekanizması olmasının neden uygun olmadığını ve bu uygulamanın olumsuz taraflarını farklı ülkelerdeki yeminli/tasdikli çeviri uygulamaları ile karşılaştırarak ortaya koymayı amaçlamaktadır. Ayrıca çalışmada, yeminli çeviri konusunda yaşanan olumsuzlukların düzeltilebilmesi ve çevirmenlik mesleği açısından daha doğru bir yetkilendirme sistemi oluşturulabilmesi için yapılabileceklere de yer verilmiştir.

Anahtar kelimeler: Yeminli çeviri, tasdikli/noter tasdikli çeviri, yeminli çevirmenlik, Noterlik Kanunu.

\section{Certified translations: A general overview on sworn translation in Turkey and sworn/ certified translation procedures around the world}

\author{
Abstract \\ The proof of the validity and reliability of the translation of a document requires official confirmation \\ of the translation and this process is generally defined as "sworn/ authorized/ certified translation". \\ $1 \quad$ Dr. Öğr. Üyesi, Bolu Abant İzzet Baysal Üniversitesi, Yabancı Diller Yüksekokulu, Mütercim Tercümanlık Bölümü (Bolu, \\ Türkiye), mugenazan@hotmail.com, ORCID ID: 00oo-0001-8983-4367 [Makale kaylt tarihi: 20.02.2020-kabul tarihi: \\ 20.03.2020; DOI: 10.29000/rumelide.706503]


Certified translations: A general overview on sworn translation in Turkey and sworn/ certified translation procedures around the world / N. M. Uysal (pp. 709-724)

\begin{abstract}
The term "sworn/ authorized/ certified translation" includes two main concepts: the authorization process of sworn/certified translators to work in this field and the authority itself giving official permission to translators who will work in this field. The procedures of the certification of a translated document vary across different countries depending on the differences within the judicial systems of countries. Yet, generally the authority responsible for the selection of sworn/certified translators is a governmental institution or a translator association and the selection criterion involves an examination which tests the translation and language competence of the applicant. In Turkey, sworn translators are authorized by notaries on the basis of Notary Public Law and translators have to take the certificate of oath from the notary to be a sworn translator. However, the official confirmation of the notary is still required for the translated document to be a certified translation. The Notary Public Law dates back to the 1970's when translators used to work in the offices of notaries. Translation industry has been expanding rapidly and today sworn translators are not members of notary offices anymore. That's why, the fact that articles related to translation procedures in the Notary Public Act 1972, which was designed for the status of sworn translators in the 1970's, is still being used for the authorization of sworn translators in Turkey is improper. This leads to negative impacts both for translators working in this field and for the translation profession. This study aims to reveal these negative impacts investigating the relationship between notaries and sworn translators in Turkey from a historical perspective and comparing the procedures involving sworn/ authorized/certified translation in different countries with the status of sworn translation in Turkey today. The study also involves suggestions for the improvement of the negative sides of the current notarized translation system and the establishment of a better authorization system for sworn translation and translation profession in Turkey.
\end{abstract}

Keywords: Sworn translation, certified/ authorized /notary certified translation, sworn/certified translators, the Notary Public Law in Turkey.

\title{
1. Giriş
}

Ülkemizde çevirmenlik mesleğinin durumu ve çevirmenlerin sorunlarına yönelik çalışmaların günden güne arttığı görülmektedir. Bu artışın bir sebebi, büyüyen hacmiyle birlikte, çeviri piyasasının fark edilen, tanınan, önemi kavranmaya başlanan bir sektör olması, bir diğer sebebi de çeviribilimdeki sosyolojik paradigmanın etkisiyle çevirmenlerin birer araştırma öznesi haline gelmeye başlamasıdır. Çevirmenlik mesleği ile ilgili çalışmalarda genellikle, çevirmenlikte dernekleşme, çevirmen eğitimi ve çeviri ile ilgili yasal düzenlemelerin neler olduğu araştırılmıştır (Uysal, Odacıŏ̆lu \& Köktürk, 2015; Uysal, 2017; Kobya \& Karabacak, 2015; Seymen \& Aslan, 2019). Çevirmenlerin yaşadığı sorunlara eğilen çalışmalarda ise kamu kurumlarında veya serbest çevirmen olarak faaliyet gösteren çevirmenlerin karşı karşıya kaldığı sorunlar tartışılmıştır (Ersoy \& Odacıoğlu, 2014; Odacıoğlu, Barut \& Odacıŏ̆lu, 2018). Yeminli çeviri konusuna odaklanan bir araştırma olan "Çeviri Bürolarında Çeviri ve Çevirmenlik" isimli çalışmada Yener (2004), ülkemizde yer alan çeviri faaliyetlerinin önemli bir bölümünü oluşturan yeminli çeviri konusunu irdelemiş, yeminli çevirmenliğin tarihçesi, çeviri bürolarının işleyişi ve çeviri büroları ile birlikte çalışan çevirmen profilleri ve bu alanda çevrilen metinlerin özellikleri gibi konulara değinmiştir.

Pym, Grin, Sfreddo \& Chan tarafından 2012 yılında yeminli çeviri kavramı ve yeminli/tasdikli çeviri ile ilgili farklı ülkelerde gerçekleştirilen uygulamalara dair "Çeviri ve Çok dillilik: Çevirmenlik Mesleğinin Avrupa Birliği’ndeki Durumu” isimli oldukça kapsamlı bir araştırma raporu hazırlamıştır. Bu raporda yer alan bilgilere göre çevirmenlerin yeminli çeviri yapma konusunda yetkilendirilmesinde ülkelere göre 
farklılıklar olabilmektedir. Pym vd. (2012, s. 26) çevirilere resmi geçerlilik kazandırılması sürecine noterler veya benzer bir resmi merciinin tasdik etme işlevi ile müdahil olduğu ülkeler bulunduğundan söz eder (ör. Kıbrıs, Yunanistan, İtalya, Letonya ve Litvanya gibi). Fakat araştırmaya dâhil edilen ülkelerin hiçbirinde ülkemizde yer alan uygulamaya (yeminli çevirmenlerin seçimi ve yetkilendirilmesinin noterler tarafindan yalnızca dil belgesi/ diploma gibi belgelere bakılarak yemin zaptı düzenlenmesi yoluyla yapılması ve yetkilendirilen çevirmenlerin ürettikleri çevirilerin resmi geçerlilik kazanması için tekrar noterlerce onaylanması) benzer bir örnek görülmemiştir. Ülkemizdeki noterlik uygulamasının çevirmenlik için olumsuz bir tablo oluşturduğuna ve bu olumsuzlukların önüne geçilebilmesi için ne gibi değişikliklerin yapılabileceğine çeşitli çalışmalarda değinilmiştir (Altay \& Ateşman, 2012, s. 3; Ersoy \& Odacioğlu, 2014, s. 372; Kartal, 2012, s. 42; Kurt, 2012, s.49-52; 56). Fakat Türkiye'de yeminlik tercümanlık müessesesinin ortaya çıkışına, günümüzde nasıl uygulanıyor olduğuna, bu uygulamaların çevirmenler ve çevirmenlik mesleği açısından ne gibi olumsuzluklar teşkil ettiğine ve farklı ülkelerde benzer uygulamaların nasıl yapıldı̆̆ına odaklanan çalışmalar çeviribilim literatüründe pek yer almamaktadır. Bu makalenin temel amacı yeminli çeviri kavramını ve yeminli çevirmenliğin ülkemizdeki tarihçesini ve günümüzdeki durumunu incelemek, farklı ülkelerde yeminli/tasdikli çeviri konusunda yapılan uygulamalarla karşılaştırmalar yaparak ülkemizdeki uygulamanın çevirmenlik mesleği ve çevirmenler açısından olumsuzluk teşkil eden yönlerine dikkat çekmektir.

$\mathrm{Bu}$ amaçla çalışmada öncelikle, yeminli veya tasdikli çeviri olarak adlandırılan çevirilerin resmiyet kazanmasının ne anlama geldiği ve bu resmiyet kazandırma işleminin hangi yollarla yapılabildiği açıklanmıştır. Daha sonra, ülkemizde yeminli tercümanlı̆̆ın ortaya çıkışına ve günümüzde yeminli çeviri konusundaki uygulamaların dayanak noktası olan Noterlik Kanunu ve Noterlik Kanunu Yönetmeliği'nde yer alan çeviri işlemler ile ilgili kanun maddelerine değinilmiştir. İlgili kanunun ortaya çıkışından sonra artan çeviri ihtiyacı ve başlı başına bir sektör haline gelen çeviri ile ilgili Noterlik Kanunu'nda yer alan maddelerin yetersiz kaldığı bazı durumlarda uygulanmak üzere yürürlüğe konan birtakım genelgeler bulunmaktadır. Dolayısıyla Noterler Birliği tarafından yayınlanan bu genelgelere de yer verilmiştir. Çalışmanın son bölümünde ise, yeminli/tasdikli çeviri konusunda farklı ülkelerde gerçekleştirilen uygulamalar irdelenmiş ve bu bilgilerle karşılaştırmalar yaparak ülkemizdeki yeminli tercümanlık müessesesi değerlendirilmiştir. Böylelikle, Türkiye'deki noter-yeminli çeviri/çevirmen ilişkisinin çevirmenlik mesleği ve yeminli çevirmenler için ne gibi olumsuzluklara sebep olduğu ortaya koyulmaya çalışılmış, sorun teşkil eden uygulamaların değiştirilmesine yönelik çözüm önerileri de çalışmaya dâhil edilmiştir.

\section{Bir çevirinin resmi olarak onaylanması neyi ifade eder?}

Pym vd. (2012, s. 23), bir çevirinin resmi olarak onaylanması veya resmi evrakların/ resmi kurumlarda kullanılacak belgelerin çevrilmesi konusunda zaman zaman birbirine karıştırılan iki farklı çeviri alanının olduğuna dikkat çekmiş ve bu alanları şu şekilde tanımlamışlardır. "Tasdikli/yeminli çeviri” olarak bilinen çeviri faaliyeti, bir çevirmenin yetkili bir mercii tarafından belirli kriterler doğrultusunda resmi evrakların çevirisini yapabilmek üzere yetkilendirilmesini ifade eder. Bu çevirmenler de "yeminli çevirmen”" (sworn translator) olarak adlandırılır. Ülkemizde bu alanda faaliyet gösteren çevirmenler için yeminli tercüman ifadesi de kullanılmaktadır. Bu çalışma alanının yanı sıra, özellikle Adalet Bakanlığı, mahkemeler ve adliyeler gibi bazı resmi kurumlarda kullanılacak hukuk metinlerinin çevirilerini yapmak üzere çevirmenler ayrıca yetkilendirilebilmektedir. Ülkemizde bu alanda çalışan

$2 \quad$ Aksi belirtilmedikçe tüm çeviriler bana aittir. 
Certified translations: A general overview on sworn translation in Turkey and sworn/ certified translation procedures around the world / N. M. Uysal (pp. 709-724)

çevirmenler "adli yeminli tercüman veya tercüman bilirkişi” (legal translator) olarak isimlendirilir. Araştırmacılar, yeminli çevirmenliği bir üst alan adı olarak kabul edip adli yeminli tercümanlığı bu alanın bir alt dalı olarak sınıflandırmıştır3. Bu çalışma, yeminli çevirmenlik ve yeminli/tasdikli çeviri konusuna odaklanmaktadır. Adli yeminli tercümanlık/Tercüman bilirkişilik çalışmanın kapsamı dışındadır.

Pym vd.(2012, s. 25-26)'nin yapmış olduğu çalışmada, “yeminli çevirmenlik” olarak adlandırılan çeviri alanında çevirmenlere verilen bu yetkinin hangi ölçütlere dayanarak ve hangi mercii/ler tarafından verildiği araştırılmıştır. Çevirmenler çevirdikleri bir metni mühür, imza vb. yollarla onayladıklarında genellikle çevirinin doğru olarak yapıldığını garanti etmiş olurlar ancak bu onayın resmiyet kazanabilmesi için çevirmenin yeminli çeviri yapmak üzere bir kurum/ mercii tarafından yetkilendirilmiş olması gerekmektedir. Bu yetkilendirme işlemi ise birkaç farklı uygulama ile yapılmaktadır. Bu uygulamalar üç ana başlıkta toplanabilir ve her bir başlık altındaki faaliyetler aşağıdaki şekilde özetlenebilir:

1. Noterler/ benzer bir resmi mercii tarafindan onaylanan çeviriler: Bu başlıkta yer alan uygulamada, adalet sistemi çevirinin bu alanda çeviri yapmaya yetkin bir çevirmen tarafindan yapılmasından ziyade bir noter veya resmi olarak yetkilendirilen benzer bir mercii tarafından onaylanmasını gerekli kılmaktadır. Ülkemizde uygulanan haliyle, bu sistemde yeminli çevirmen olarak görev yapacak olan kişilere karar veren de yine noterler olmaktadır. İlgili kanunun gerekli kıldığ evrakları sunabilen kişiler noterlerin kanaat getirmesiyle bir yemin zaptı imzalayarak yeminli çevirmen unvanına sahip olabilmektedir. Ancak yeminli çevirmenlerin yaptıkları çevirilerin resmiyet kazanabilmesi için bu belgelerin ayrıca noterler tarafından da onaylanması gerekmektedir. Böylelikle belgenin bir yeminli tercüman tarafından çevrilmiş olduğu noterin onayı ile tasdik edilmiş olur. Bu durumda, çevirinin resmiyet kazanabilmesi için çevirmenin onay yeterli olmamakta, noter tasdiki de gerekmektedir. Yeminli çevirmenlik konusunda ülkemizdeki uygulamalar bu şekilde yapilmaktadir.

2. Bir devlet kurumu veya bir eğitim kurumu tarafından yetkilendirilmiş yeminli çevirmenler tarafindan onaylanan çeviriler: Almanya, Romanya, Slovenya ve İspanya gibi bazı ülkelerde, Adalet Bakanlığı veya Dış İşleri Bakanlığı gibi devlet kurumları "yeminli çevirmen" 4 olarak görev yapmak isteyen kişileri belirli sınavlara tabi tutar. Yalnızca bu sınavlarda başarılı olan adaylar bu unvanı kullanarak tasdikli çeviri yapma hakkına sahip olur. Bu çevirmenler tarafından yapılmış olan çevirilerin genellikle noter veya başka bir mercii tarafından ayrıca onaylanması gerekmemektedir. Çevirilerin resmi onay kazanması ile ilgili bir diğer uygulama ise yeminli çeviri yapacak olan kişilerin gerekli görülen eğitim koşullarını tamamlamış olmasıdır. Bu durumda, adayların hukuk metinleri çevirisi ve/veya hukuk sistemleri ile ilgili ders(ler)in yer aldığı bir mütercim-tercümanlık/çeviribilim bölümünde eğitim almış olmaları beklenir.

3. Bir meslek örgütü tarafından yetkilendirilmiş çevirmenler tarafindan onaylanan çeviriler: Yeminli çeviri ile ilgili düzenlemelerin yer almadığı İngiltere, Amerika, Kanada ve Avustralya gibi bazı ülkelerde köklü meslek örgütleri tarafından uygulanan sinavlar sonucunda çevirmenler sertifika almaya hak kazanırlar ve bu sertifika ile elde ettikleri unvanı yaptıkları çevirilerde kullanabilirler. Bu uygulamada çevirmenlerin yetkilendirilmesi bir meslek örgütü tarafından yapılmaktadır (Uysal, 2017).

Ülkemizde çeviri metinlerin resmi olarak onaylanması yukarıda yer verilen uygulamalardan birincisi ile gerçekleştirilmektedir. Türkiye'de hem bir çevirmenin yeminli çevirmen unvanı ile çalışabilmesi hem de bu çevirmenin ürettiği bir çevirinin resmiyet kazanabilmesi ve resmi makamlarda işlem görebilmesi noterlik müessesesi vasıtasıyla yapılmaktadır. Çeviri açısından noter onayı, yazılı bir belgenin

Ülkemizde adli yeminli tercümanlı/tercüman bilirkişilik ile ilgili düzenlemeler 5271 Sayll Ceza Muhakemesi Kanunu'nun ilgili maddeleri uyarınca yapılmaktadır. Tercüman bilirkişi olarak kabul edilen kişiler Adalet komisyonları huzurunda yemin ederek 1 yll süre ile adli yeminli çeviri yapabilirler.

4 Avrupa ülkelerinde aynı anlamda yaygın olarak kullanılan bir diğer terim “devlet tarafından yetkilendirilmiş çevirmen”dir. 
"doğruluğundan, gerçekliğinden ve güvenilirliğinden şüphe olmadığını göstermek amacıyla hem resmiyette, hem de özelde devlet adına yapılan” tasdik işlemi olarak tanımlanabilir (Kurt, 2012, s. 51).

\section{Türkiye'de yeminli tercümanlık müessesesinin ortaya çıkışı}

Osmanlı Devleti’nde Tercüme Kalemi aracılığıyla yürütülen bürokratik çeviri ihtiyacının Cumhuriyet Dönemi’nde bu geleneğin devamı olarak "alaylı" çevirmenlerce yapıldığı görülmektedir. Bu alaylı çevirmenlerin hukuki dayanağı ise bugün de yeminli tercümanlık müessesinin temelini oluşturan Noterlik Kanunu'dur. Noterlik Kanunu'nun ortaya çıkışı 1913 yllına dayanmaktadır. İlk kez Katib-i Adil adı ile uygulamaya geçmiş olan kanun 1926 yılında Noterlik Kanunu adını almış, 1938 yılında 3456 Sayılı Noterlik Kanunu olarak, 1972'de 1512 Sayılı Noterlik Kanunu olarak değiştirilmiştir. T.C. Başbakanlık İdareyi Geliştirme Başkanlığı tarafından hazırlanan ve 2015 yılında yayınlanan Çevirmenlik Mesleği Araştırma Raporu'na göre, 1512 Sayılı Noterlik Kanunu'nun yürürlüğe girdiği 1970’li yıllarda ülkemizde henüz bir çeviri sektöründen bahsetmek mümkün değildi ve noterlerde maaşlı olarak çalışan çevirmenler bulunmaktaydı (T.C. Başbakanlık İdareyi Geliştirme Başkanlığı [BİGB], 2015, s. 56). Bu durum, bugün çeviri büroları tarafından yürütülen çeviri işlerinin o dönemde noterler tarafından yapılıyor olduğunu düşündürmektedir. Zira Yener (2004)'in de belirttiği üzere, ticari olarak çeviri faaliyeti yürüten büroların ilk kez ne zaman ortaya çıktığına dair resmi bir kayıt bulmak oldukça zordur. Çünkü şirketler ticaret sicil kayıtlarında meslek gruplarına göre sınıflandırılmaktaydı, fakat çeviri veya tercüme, bir meslek grubu olarak tanımlanmadığından böyle bir sınıflandırma söz konusu değildi. Çeviri faaliyetinde bulunan şirketler o tarihlerde genellikle "özel eğitim ve öğretim kurumları", "filmcilik, reklamcılık, tiyatro, sinema", "mali müşavirler", "inşaatçılar" gibi çeşitli meslek grubu başlıkları altında yer alıyordu. İlgili döneme ait ticaret sicil kayıtları bu şekilde incelendiğinde, en eski çeviri bürosunun 1979 yılında kurulduğu görülmektedir. 80'li yıllarda çeviri büroları çok yaygın değildir. Ancak serbest piyasa ekonomisiyle ithalat ve ihracat faaliyetleri gelişmeye başlamış ve kurumların ihtiyaç duyduğu çeviri faaliyeti arttıkça çeviri büroları yaygınlaşmaya başlamıştır. Bu gelişmeye paralel olarak, aynı dönemlerde, çeviri faaliyetlerinde değişen ihtiyaçlara bağlı olarak ortaya çıkan sorunlara yönelik Noterler Birliği’nin çeşitli genelgeler yayınladığı görülmektedir (s. 6-7).

\section{4. Çeviri etkinliğinde noter, çevirmen ve çeviri bürosu ilişkisi:}

1970’lerden bugüne gelindiğinde, noterlik bürolarında çalışan yeminli tercümanların varlığından söz edemiyoruz artık. Aradan geçen zamanla birlikte, çeviri ihtiyacının artması ve çevirinin başlı başına bir sektör haline gelmesiyle, noter ve çevirmen arasındaki ilişkide üçüncü bir aktör olarak çeviri bürolarını görüyoruz. Müşteri ve çevirmen arasında bir aracı olarak faaliyet gösteren çeviri bürolarında çevirmenler büronun çalışanı olarak faaliyet gösterebildiği gibi serbest çevirmen olarak da çeviri bürolarının ihtiyaçlarını karşlayabilmektedir. Yener (2004, s. 11) çeviri bürolarındaki işleyişle ilgili bilgilere yer verdiği çalışmasında noter, çevirmen ve çeviri bürosu arasındaki ilişkiyi aşağıdaki şekilde tanımlamıştır:

\begin{abstract}
Yemin belgesi düzenlenen çevirmen, Noterlik Kanunu uyarınca, Noterlik dairesinin yeminli çevirmeni olarak görülmektedir. Yeminli çevirmen, çeviri bürosuyla, eğer büroda çalışıyorsa işçiişveren, dışarıdan bağımsız olarak çalışıyorsa, yüklenici-alt yüklenici ilişkisine [bu ilişki, aynı çalışmada, müteahhit-taşeron ilişkisine benzetilmiştir] sahiptir. Noterlik ve çeviri bürosu arasında yasal bir bă̆ bulunmamaktadır. [Öte yandan,] çevirmeni ve çeviri bürosunu aynı kişi olarak düşündüğümüzde böyle bir bağ kurulabilir. [Diğger bir deyişle,] noterlik ve yeminli çevirmen arasındaki bağ, noterlik ve çeviri bürosu arasındaki bağla aynı şeyi ifade etmektedir.
\end{abstract}

Adress

Kirklareli University, Faculty of Arts and Sciences, Department of Turkish Language and Literature, Kayalı Campus-Kırklareli/TURKEY e-mail: editor@rumelide.com 
Noter onaylı bir çevirinin nasıl ortaya çıtığını inceleyerek de çevirmen, noter ve çeviri bürosu ilişkisi irdelenebilir. Genellikle, bir müşteri noterde düzenlettirdiği herhangi bir evrakın çevirisine ihtiyaç duyduğunda, noter bu müşteriyi kendisinde yemin zaptı bulunan bir çevirmene veya bu çevirmenle çalışan bir çeviri bürosuna yönlendirir. Çevirmen yaptığı çevirinin aslına uygun olduğunu beyan eden ibarenin altına imzasını atar. Şayet çevirmen bir çeviri bürosunda çalışıyorsa, evrak çeviri bürosu tarafından da mühürlenir. Son olarak, çevirmenin yemin zaptının bulunduğu noterin de belgeyi mühürlemesiyle çeviri tam olarak resmiyet kazanmış olur (a.g.e, s. 11). Ülkemizde resmi çeviri faaliyetleri bu şekilde gerçekleştirilir. Şayet müşteri için tercüme bürosu tarafından tasdik edilen çeviri yeterli oluyorsa ayrıca noter onayı alınmasına gerek yoktur. Ancak, resmi makamlara sunulacak belgeler için genellikle noter onayı alınması gerekir.

\subsection{Türkiye'de yeminli tercümanlık, çeviri mevzuatı ve Noterlik Kanunu:}

Ülkemizde, yeminli tercümanlık ve çeviri evrakların resmiyet kazanması ile ilgili bir çeviri mevzuatı bulunmamaktadır, bu konulardaki yasal düzenlemeler Noterlik Kanunu ve Noterlik Kanunu Yönetmeliği kapsamında yapılmaktadır. Noterlik Kanunu'nun sekizinci kısım birinci bölümünde "Noterlerin Genel Olarak Yapacakları İşler" başlığı altında yer alan 6o.madde'de "[b]elgeleri bir dilden diğer dile veya bir yazıdan başka bir yazıya çevirmek" ifadesi yer almaktadır, bu da çevirinin noterin yaptığı işler arasına dâhil edildiğini göstermektedir (Noterlik Kanunu, 1972).

İlgili kanunun dokuzuncu kısım birinci bölümünde "Noterlik İşlemlerinde Uyulması Gereken Genel Hükümler" açıklanır. Noterin hangi durumlarda tercüman bulundurması gerektiği Madde 74 ve Madde 75 'te belirtilir.

\section{Ilgilinin Türkçe bilmemesi:}

Madde 74 - Illgili, Türkçe bilmezse andlı bir tercüman da bulundurulur.

İmza yerine işaret, mühür veya parmak izi kullanılması:

Madde 75 -illgililerle tanık, tercüman ve bilirkişi imza atamadıkları ve imza yerine geçen bir el işareti kullanmadıkları takdirde, varsa mühür, yoksa sol elinin başparmağı, bu da yoksa diğer parmaklarından biri bastırılır ve hangi parmağın bastırıldı̆̆ı yazılır...

Tanık, tercüman ve bilirkişinin andı noter tarafından Hukuk Yargılama Usulü Kanunu uyarınca yaptırllır (a.g.e, 1972, vurgu bana ait).

Yukarıda yer alan bilgiye göre, Noter tercüman bulundurması gereken durumlarda tercümanı resmi olarak yetkilendirebilmek için bir noter andı düzenlemek zorundadır. Yetkilendirme işleminin nasıl yapılacağı Noterlik Kanunu Yönetmeliği'nde yer alan Madde 96'da açılanmıştır. Bu maddede çevirinin tanımına, çevirmenin hangi usullerle yeminli tercüman olacağına, çevirme işleminin noterin gelirlerinden sayıldığına ve çevirme işlemlerinden alınacak ücretlerin ne şekilde belirleneceğine ilişkin bilgiler yer alır. Burada yer alan bilgiler adeta çeviri ile ilgili Noterlik Kanunu'nun farklı bölümlerinde görülen düzenlemelerin bir özeti niteliğindedir. Yönetmeliğin 96. maddesi şu şekildedir:

Çevirme işlemleri

Madde 96 - Belgelerin bir dilden diğer dile veya bir yazıdan başka bir yazıya çevrilmesine ve noterlikçe onaylanmasına çevirme işlemi denir.

Noterin, çevirmeyi yapanın o dili veya yazıyı doğru olarak bildiğine, diplomasını veya diğer belgelerini görerek veya diğer yollarla ve hiçbir tereddüde yer kalmayacak şekilde kanaat getirmesi gerekir.

Noterlik Kanunu'nun 75. maddesinin son fikrası gereğince noter tercümana Hukuk Yargılama Usulü Kanunu'na göre and içirir. Bunun bir tutanakla belgelendirilmesi zorunludur. Bu tutanakta 
tercümanın adı, soyadı, doğum tarihi, iş adresi, ev adresi, tahsil derecesi, hangi dil veya dilleri, hangi yazıyı bildiği, noterin çevirenin bu dil ve dilleri veya yazıyı bildiğine ne suretle kanı sahibi olduğu, yemin biçimi ve tutanağın tarihini gösterir. Tutanağın altı noter ve tercüman tarafından imzalanır.

Kendisine çevirme yaptırılan kimselerin yemin tutanakları noterlik dairesinde özel bir kartonda saklanır. Noter, kartonunda yemin tutanağı bulunmayan bir kimseye çevirme yaptıramaz.

Noter tarafından ilgilisinden alınan çevirme ücretleri noterlik dairesinin gelirlerinden olup, yevmiye defterine gelir olarak kaydedilir. Noterin çevirene ödediği para da dairenin giderlerindendir.

Çevirme ücreti hesaplanırken, çevrilmesi istenilen yazının sayfaları değil, çevirme yapıldıktan sonra noter tarafından yazdırılan sayfa sayısı esas tutulacaktır.

Çevirme işleminin, ilgilinin bulunduğu yer noterliğinde yaptırılması mümkün bulunmayan hallerde, o noterlik aracılığı ile başka bir yer noterliğinde çevirme yaptırılabilir. Bu takdirde, ilgiliden ayrıca, aracılık ücreti de tahsil olunur (Noterlik Kanunu Yönetmeliği, 1976, vurgu bana ait).

Noterlik Kanunu Yönetmeliğinin 96. maddesinden de anlaşllabileceği gibi, çeviri, noterin gelirleri arasında sayılmaktadır. Noterlik Kanunu'nun birinci kısım, birinci bölümünde de benzer bir bilgiye rastlanmaktadır. Bu maddede noterlerin verdikleri hizmetler karşılığında alacakları ücretler listelenmiştir ve çevirme işlemi de noterin gelir sağladığı işlemler arasında yer almaktadır.

Madde 112 - Noterlerin yaptıkları işlemlere ait harç üzerinden hesaplanacak ücretleri ile vasiyetname ve vakıf senedi düzenlenmesinden alınacak ücretler, yazı, bir dilden diğer dile veya bir yazıdan diğer yazıya çevirme, karşılaştırma, tescil, emanetlerin saklanması ve kanunlarında harç, vergi ve resimlerden bağışık olduğu yazılı işlemler ile defter onaylanmasından ve kanunun ücret almayı öngördüğü sair işlemlerden alacakları ücretler ve noterlerle imzaya yetkili vekillerinin yol ödeneğinin miktarı, Türkiye Noterler Birliğinin mütalaası alındıktan sonra Adalet Bakanlı̆̆ı tarafindan düzenlenecek bir tarife ile tespit olunur (a.g.e., 1976, vurgu bana ait).

Özetle, ülkemizde bağımsız bir çevirmenlik yasası bulunmadığından, "yeminli çeviri” olarak adlandırılan çeviri alanında, çevirisi yapılan belgelerin resmi geçerliliğe kavuşması ve bu tür belgelerin çevirisini yapacak olan yeminli tercümanların belirlenmesi için yasalar tarafından noterler yetkilendirilmiştir. Çeviri işlemleri ile ilgili düzenlemeler, Noterlik Kanunu ve Noterlik Kanunu Yönetmeliği içerisinde yer alan maddelere dayanarak yürütülmektedir.

\section{2. Çeviri ile ilgili işlemler kapsamında Türkiye Noterler Birliği tarafından yayınlanan genelgeler}

1972 yılında yürürlüğe girmiş olan Noterlik Kanunu ve Noterlik Kanunu Yönetmeliği, yukarıda da görüldüğü gibi, çeviri ile ilgili resmi düzenlemelerin usullerine ilişkin bilgilere yer vermektedir. Ancak kanunun kabul edildiği tarihten sonra çeviri ihtiyacının artması ve çevirinin yaygınlaşması, kanunun kapsamadığı bazı konularda ortaya çıkan sorunlara yönelik çözümler geliştirilmesini gerektirmiş, bu sebeple, Türkiye Noterler Birliği, farklı zamanlarda çeşitli genelgeler yayınlayarak mevcut olan mevzuata yeni bilgiler eklemiştir. Yener (2004, s. 13-15) bu bağlamda yayınlanmış altı genelge bulunduğunu belirtmektedir. Bu genelgelerle ilgili bilgiler kısaca şu şekildedir:

23.1.1990 Tarihli 5 Sayılı Genelge'de yurtdışına gönderilecek adli evrak tercümelerinin noksansız ve doğru bir biçimde yapılabilmesi için tercüman seçiminde dikkat ve özen gösterilmesi gerektiği belirtilmektedir.

2.6.1992 Tarihli 27 Sayılı Genelge'de yabancı dilde yazılmış, resmi merci onayı taşımayan belgelerin Türkçeye çevrilebileceği, ancak resmi makam onayı taşımamalarından dolayı tereddüte düşüldüğü takdirde belgenin altına şerh düşülmesi yoluyla yanlış anlamaların giderilebileceği ifade edilmiştir. 
Certified translations: A general overview on sworn translation in Turkey and sworn/ certified translation procedures around the world / N. M. Uysal (pp. 709-724)

22.11.1993 Tarihli 9o Sayılı Genelge yabancı statüsündeki kişilerin noterlikçe yeminli tercüman olup olamayacaklarına ilişkindir. Bu genelgede yer alan bilgilere göre, noterlik işlemlerinin resmi niteliği ve gizliliği bulunduğu için yabancı uyruklu kişilerin yeminli tercüman olarak çalıştırılmaması gerekir. Fakat İçişleri Bakanlığı’ndan çalışma izni almış olan Türk soylu yabancı uyruklu kişiler yeminli tercümanlık yapabilir.

8.2.1995 Tarihli 11 Sayllı Genelge'de bir işyerinde işçi statüsünde çalışan tercümanın aynı işyerinin yöneticilerinin, yani işverenlerinin, bulundukları bir noterlik işlemine tercüman olarak katılmasının uygun olmayacağı ifade edilmiştir. Çünkü böyle bir durum suistimallere açıktır ve menfaat çelişkisi doğurabilir.

23.01.1997 Tarihli 2 Sayılı Genelge ile çevirilerde asıl belgenin fotokopisi veya örneğinin çeviri evrakına eklenmesinin bir sakınca teşkil etmeyeceği ve çeviri işlemlerinde çeviriye asıl yazının suretinin eklenmesi halinde maktu suret harcı alınması gerektiği belirtilir.

8.4.1997 Tarihli 38 Sayılı Genelge faksla gelen veya fotokopisi ibraz edilen belgelerin tercüme usullerini kapsamaktadır. İlgili genelgeye göre, noterlere bu şekilde çevrilmesi için sunulan evrakların çevirileri yapılabilir fakat suret üzerinden yapılan çeviri işlemlerinde "faks veya fotokopiden tercümedir" ve "işbu tercüme ibraz edilen kimlik, diploma veya pasaport fotokopisi veya faksı görülerek tercüme edilmiştir" ibarelerinin yer alması gerekmektedir. Ayrıca, işlemi yaptıran kişinin açık kimliği ve adresinin yazılması gereklidir.

Daha önceki bölümlerde de ifade edildiği gibi, 9o'lı ylllar Türkiye'deki çeviri ihtiyacının ve çeviri bürosu sayısının artmaya başladığı yıllardır. Yukarıda bahsi geçen genelgelerin tümünün de bu dönemde çıkarılması meydana gelen bu hızlı değişimin bir sonucu olarak kabul edilebilir. Bu bölümde son olarak, Noterler Birliği tarafından 2010 yılında çevirme işlemlerinde noterlerin müşterilerden talep ettikleri çevirme ücreti konusunda çıkarılmış ancak 2016 yılında yürürlükten kaldırılmış olan 21.01.2010 Tarihli 7 Sayllı Genelge'ye değinilecektir.

21.01.2010 Tarihli 7 Sayılı Genelge ile çevirme işlemlerinde noterlerce müşteriden talep edilen çevirme ücretinin yarısının tercümana ödenmesi gerektiği ifade edilir. 2016 yllında yürürlükten kaldırılan genelgenin iptal edilmesine yönelik Türkiye Çevirmenler Derneği’nin (TÜÇED) internet sitesinde dernek başkanı Ahmet Varol tarafından yazılmış olan "Noter ile ilgili Meslektaşlara Duyuru" başlıklı bir açıklama yer almaktadır. Bu açıklamaya göre,“[ç]evirme işlemleriyle ilgili olarak, noterlik ücret tarifesine göre tahakkuk eden çevirme ücretinin tamamının tahsil edilmesinden sonra, \%50'sinin noterler tarafından tercümanlara ödeneceğine ilişkin 21.01.2010 tarihli ve (7) sayllı genelgenin iptali ve yürütmesinin durdurulması istemiyle” bir noter tarafından dava açılmış, fakat Danıştay Sekizinci Dairesi tarafından yürütmenin durdurulması istemi reddedilmiştir (Türkiye Çevirmenler Derneği, t.y.). Daha sonra, davacı bu karara itiraz etmiş ve davacının itirazı Danıştay İdari Dava Daireleri Kurulu tarafından kabul edilmiş ve dava konusu işlemlerin yürütülmesinin durdurulmasına, yani 21.01.2010 tarihli ve (7) sayılı genelgenin yürürlükten kaldırılmasına, karar verilmiştir. Bu karara göre, noter tarafından müşteriden alınan çevirme ücretleri noterlik dairesinin gelirleri arasında sayılmaktadır ve konu ile ilgili işlemlerin Noterlik Kanunu Yönetmeliği hükümlerine uygun şekilde yapılması gerektiği belirtilmiştir.5 Bir önceki bölümde ifade edildiği gibi, çevirme işlemleri için alınan ücretler Noterlik Kanunu Yönetmeliği’nin 96. maddesine göre noter dairesinin gelirlerinden kabul edilir. Çevirme

21.01.2010 Tarihli 7 Sayılı Genelge ile ilgili detaylı bilgi için bkz http://www.tuced.org.tr/; https://www.turcef.net/turcefuyesi-cevirmen-ve-ceviri-burolarinin-dikkatine 
işlemleri ile ilgili ücretlendirmeler ise Harçlar Kanunu'na göre yapılır. Harçlar Kanunu'nun 135. maddesine göre 50 harf 1 satır, 20 satır 1 sayfa olarak kabul edilir. Bugün çeviri bürolarında da çeviri ücretlerinin hesaplanmasında kullanılmakta olan "boşluksuz 1000 karakter" ifadesi de bu kanuna dayanmaktadır. Çevirme işlemlerine ilişkin noterlerin tahakkuk edeceği ücretler için yıllık bir taban fiyat belirlenir ve noterlik ücret tarifesi ismiyle Resmi Gazete'de yayınlanır'6.

\section{5. Çevirilerin resmi olarak onaylanması konusunda ülkemiz dışındaki uygulamalara genel bir bakış: Çeşitli ülkelerdeki yeminli çeviri / tasdikli çeviri uygulamaları}

Çalışmanın ilk bölümünde, Pym vd. (2012)'nin bulgu ve değerlendirmelerinden yola çıkılarak yapılmış olan sınıflandırmada çevirilere üç farklı uygulama ile resmi bir nitelik kazandırıldığı ifade edilmişti. Ülkelerin adalet sistemlerinde yer alan düzenlemeler çerçevesinde bir çeviri ya bir noter tarafından onaylanmak suretiyle resmiyet kazanabilmekte ya da resmi olarak kabul görecek çevirileri yapacak çevirmenler bir devlet kurumu veya meslek örgütü tarafından yetkilendirilmekte ve bu çevirmenler tarafından üretilen metinler yeminli/onaylanmış/tasdikli çeviri sınıfına girmekteydi. Çalışmanın bu bölümünde, çevirmenliğin farklı ülkelerdeki durumunu incelemek üzere yukarıda değinilen araştırma raporuna dâhil edilen ülkelerdeki yeminli çeviri/resmi tasdikli çeviri ile ilgili düzenlemeler irdelenecektir. Almanya, Romanya, Slovenya, İspanya, İngiltere, Amerika, Kanada ve Avustralya olmak üzere toplam sekiz ülke bu araştırmada yer almaktadır ve bu ülkelerdeki uygulamaları iki başlık altında toplamak mümkündür: Almanya, Romanya, Slovenya ve İspanya'da, bir çeviriye resmi geçerlilik kazandırılması yeminli çeviri kavramı ile ifade edilmektedir. Yeminli çevirmenler ise belirli devlet kurumları tarafından yetkilendirilmektedir. Öte yandan, Amerika, Kanada, Avustralya ve İngiltere'de yeminli çeviri olarak tanımlanabilecek bir resmi çeviri kavramının bulunmadığı görülmektedir. Bunun yerine, bu ülkelerdeki bazı çevirmen örgütleri tarafından gerçekleştirilen çeviri sınavlarında başarılı olan kişiler bir sertifika sahibi olurlar ve çevirilerinde bu sertifika ile elde ettikleri unvanı kullanabilirler. Çeviriler bu şekilde resmiyet kazanmış olur.

Daha önce belirtildiği üzere, yeminli çeviri yapmak üzere çevirmenlerin yetkilendirildiği sistemlerde, bu yetkilendirme genellikle bir devlet kurumu tarafından yapılmaktadır. İlk olarak, Almanya'daki uygulamalarda, çevirmenlerin yetkilendirilmesi ile işlemler bölge mahkemeleri tarafından yapılır. Eyaletlere göre farklılıklar olabilmekle birlikte yetkilendirilme, sınav uygulaması ile yapılmaktadır. Her ne kadar bir eyalette yeminli çevirmen olmaya hak kazanmış bir çevirmen bir başka eyalette aynı statüye sahip olamıyor olsa da bir “yeminli çeviri” Almanya’nın bütün eyaletlerinde geçerli sayllmaktadır. Araştırmada yer alan bir diğer ülke olan Slovenya'da, yeminli çevirmen olarak çalışabilmek için Adalet Bakanlığı tarafından yapılan sınavı başarı ile tamamlamak gerekir. Bu sınavda başarılı olan kişiler ülkenin Adalet Sistemi içerisindeki farklı kurumlarda görev yapabilirler. Araştırmada yer alan bir diğer ülke olan İspanya'da da yeminli çevirmenlik ile ilgili uygulamalar Adalet Bakanlı̆̆’nca yürütülür. Almanya ve Slovenya'ya benzer bir şekilde, İspanya'da da yeminli çevirmenlik yılda bir kere düzenlenen yazılı ve sözlü bölümlerden oluşan bir sınavdan başarılı olmak koşuluyla elde edilen bir unvandır. Aynı zamanda, hukuk çevirisi ile ilgili dersler alarak mütercim-tercümanlık bölümlerinden mezun olmuş kişiler bu sınav uygulamasından muaf tutulmaktadır. Romanya'daki uygulamalar ise diğer üç ülkeden farklılık göstermektedir. Romanya'da Adalet Bakanlığı, noterler, hukuk büroları ve mahkemeler gibi adalet sistemi ile ilintili kurumlarda tasdikli çeviri yapacak çevirmenlerin yetkilendirilmesini Adalet Bakanlığı yapar. Adayların mütercim-tercümanlık, uygulamalı yabancı diller ve yabancı diller eğitimi gibi bir alandan lisans eğitimini tamamlamış olması veya çift dilli eğitim veren bir liseden mezun olmuş

62020 Yllı Noterlik Ücret Tarifesi için bkz. https://portal.tnb.org.tr/Tebligler/Noterlik\%20\%C3\%9Ccret\%2oTarifesi.pdf 
Certified translations: A general overview on sworn translation in Turkey and sworn/ certified translation procedures around the world / N. M. Uysal (pp. 709-724)

olması aranan bir ön koşuldur. Diğer yandan, Adalet Bakanlığı ve ilintili kurumlar dışında kullanılacak olan çeviriler için Kültür ve Ulusal Miras Bakanlığı (Ministry of Culture and National Heritage) sınav yolu ile yetkilendirme yapmaktadır. Sınava girebilmek için adayların lise eğitimlerini tamamlamış olmaları yeterlidir. Serbest çevirmen olarak faaliyet gösterebilmek için, bu yazılı çeviri sınavında başarılı olmak gerekir. Ancak, hukuk alanında çeviri yapabilmek için bu sınava ek olarak farklı sınavları da tamamlamak gerekir. Çeviri belgeler, çevirinin doğruluğunu ve geçerliliğini göstermek amacıyla yetkilendirilmiş olan çevirmenlerin imzasını ve mührünü taşır. Özellikle Adalet Bakanlığı ve bu bakanlıkla bağlantılı kurumlarda kullanılacak çeviri metinlerde ayrıca bir de noter onayı gerekebilmektedir. Noter onayının buradaki işlevi ise çevirinin Adalet Bakanlığı'na kayıtlı bir çevirmen tarafından yapıldığını belirtmektir. Almanya, Slovenya, İspanya ve Romanya'da yeminli çevirmenlik bir kere hak kazanıldığında herhangi bir yenileme şartı olmaksızın sürdürülebilen unvanlardır.

İkinci grupta yer alan ülkelerde, çeviri becerilerini belgelemek isteyen çevirmenlere yönelik, köklü meslek örgütleri tarafından sertifika sınavları düzenlenmektedir ve bu sınavlarda başarı gösteren adaylar elde ettikleri bu unvanı bir yetki göstergesi olarak çevirilerinde kullanabilmektedir. İngiltere'nin önde gelen çevirmen örgütlerinden biri olan İmtiyazlı Dilbilimciler Enstitüsü (The Chartered Institute of Translators- CIOL) yazılı ve sözlü çeviri alanlarında sınavlar düzenleyerek adaylara ilgili alanda sertifika sahibi olma imkânı sunar. Bazı hukuki metinlerin çevirilerinde resmi tasdik gerektiği durumlarda, çevirmenin sahip olduğu sertifika ile ilgili bilgilerin bulunduğu bir belge kullanılabilir. Mahkeme tercümanlığı yapacak olan adayların seçiminde CIOL ve Metropolitan Polis Teşkilatı'nın (Metropolitan Police Service) birlikte düzenlediği çeviri sınavı kullanılmaktadır (Uysal, 2017, s. 63). Amerika'da ise Amerikan Çevirmenler Birliği (American Translators Association- ATA) yazılı çeviri alanında dünyanın önde gelen çevirmen sertifikasyon sınavlarından birini düzenlemektedir. Mahkeme çevirmenliği konusunda ise eyaletlerce görevlendirilmiş ilgili birimlerin sınavları mahkemelerde görevlendirilecek tercümanların seçimi için kullanılmaktadır. Mahkemelere sunulacak evrakların çevirilerinde çevirmenin mahkeme tercümanlığı sertifikasına sahip olması istenebilmektedir. İngiltere ve Amerika'ya benzer bir biçimde Kanada'da da, Avrupa ülkelerinde ve ülkemizde var olan bir yeminli çeviri/çevirmenlik sistemi bulunmamaktadır. Bunun yerine, çevirmenler sertifika sahibi olarak sektörde yer alırlar. Kanada'daki bölgesel örgütleri bünyesinde toplayan çatı çevirmen örgütü Kanada Tercümanlar, Terminoloji Uzmanları ve Çevirmenler Konseyi (Canadian Translators, Terminologists and Interpreters Council- CTTIC) sertifikasyon ile ilgili düzenlemeleri yapmakla yükümlüdür. Sertifika sahibi olmak için adaylar ilk olarak bağlı bulundukları eyaletlerdeki bölgesel örgütler tarafindan düzenlenen çeviri sınavını ve sonrasında da CTTIC'nin yaptığı sınavı başarı ile tamamlamalıdır. Fakat Kanada Hükümeti bünyesinde yer alan idari birimlerde çevirmenlik yapmak için adaylardan bu sınavların dışında farklı yeterlilik göstergeleri istenmektedir. Bu grupta yer alan son ülke olan Avustralya'da da, bir yeminli çeviri/çevirmenlik sistemi yer almaz. İngiltere, Amerika ve Kanada'da olduğu gibi, çevirmenlerin sertifikalandırıldığı ve bu sertifikaların bir resmi onay niteliği taşıdığı görülür. Avustralya hükümetine bağlı olarak kurulmuş olan, farklı bölgesel örgütleri bir çatı altında toplayan ve ülkede çevirmen sertifikasyonu ile ilgili faaliyetleri yürüten tek kurum Mütercimler ve Tercümanlar Ulusal Akreditasyon Kurumu'dur (National Acreditation Authority for Translators and Interpreters- NAATI). Resmi işlemlerde kullanılacak çevirilerde "NAATI-sertifikalı" çevirmen mührü istenir. Mahkemelerde kullanılacak çeviri belgelerde ise ayrıca çevirilerin NAATI-sertifikalı bir çevirmen tarafından yapıldığını belirten yazılı bir onay belgesi aranır. Çevirilerin resmiyet kazanması bu yolla sağlanmaktadır.

Bu bölümde sekiz farklı ülkede yeminli çevirmenlik kavramı ve çevirilere ne şekilde resmi bir nitelik kazandırıldığı incelenmiştir. Yeminli çeviri uygulamasının yer aldığı ülkelerde bu uygulamanın devlet 
eliyle sınav sistemine dayalı olarak yapıldığı görülmektedir. Öte yandan, yeminli çeviri kavramının var olmadığı ülkelerde yeminli çevirmen diye bir unvandan da söz etmek mümkün değildir. Bu ülkelere bakıldığında, her birinde bir çatı kuruluş olarak faaliyet gösteren köklü çevirmen örgütlerinin varlığı dikkati çekmektedir ve bu örgütler uzun yıllardır çevirmenlik sınavları düzenlemekte ve başarılı olan adaylara bu yetkinliklerini belgelemek amacıyla sertifika verilmektedir. Çevirilerin resmi olarak tasdik edilmesinin gerektiği durumlarda da, çevirmenin sahip olduğu sertifika kullanılmaktadır. Bu bölümde incelenen ülkelerdeki resmi onaylı çeviri uygulamaları ile ilgili bilgilere kısaca tablo 1'de yer verilmiştir.

\begin{tabular}{|c|c|}
\hline $\begin{array}{l}\text { Yeminli çevirmenlik uygulamasının bulunduğu } \\
\text { ülkelerdeki yetkilendirme süreci: Bu ülkelerde } \\
\text { yeminli çeviri yapacak olan çevirmenlerin belirlenmesi bir } \\
\text { devlet kurumu tarafindan, genellikle bir sinav uygulaması } \\
\text { ile gerçekleştirilmektedir. }\end{array}$ & 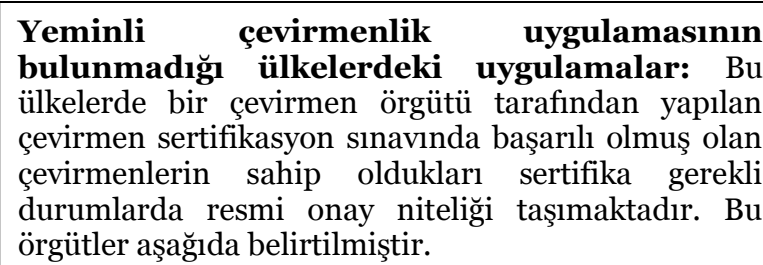 \\
\hline $\begin{array}{l}\text { Almanya: Bölge mahkemeleri } \quad \text { tarafından } \\
\text { uygulaması ile yapılır. }\end{array}$ & İngiltere: İmtiyazlı Dilbilimciler Enstitüsü (CIOL) \\
\hline $\begin{array}{l}\text { Slovenya: Adalet Bakanlığı tarafindan sinav uygulaması } \\
\text { ile yapilır. }\end{array}$ & Amerika: Amerikan Çevirmenler Derneği (ATA) \\
\hline $\begin{array}{l}\text { İspanya: Adalet Bakanlığı tarafindan sınav uygulaması } \\
\text { veya gerekli görülen eğitim faaliyetlerinin tamamlanması } \\
\text { koşuluyla yapılır. }\end{array}$ & $\begin{array}{l}\text { Kanada: Kanada Tercümanlar, Terminoloji Uzmanları } \\
\text { ve Çevirmenler Konseyi (CTTIC) }\end{array}$ \\
\hline $\begin{array}{l}\text { Romanya: Adalet Bakanlığı ve ilgili kurumlarda } \\
\text { kullanılacak çeviriler için Adalet Bakanlığı tarafindan } \\
\text { sinav uygulaması ile çevirmen seçimi yapılır. Eğitim ön } \\
\text { koşulu mevcuttur. } \\
\text { Diğer alanlarda kullanılacak resmi onaylı çeviriler için } \\
\text { çevirmen seçimi Kültür ve Ulusal Miras Bakanlı̆ı isimli } \\
\text { kurum tarafindan sınav uygulaması ile yapıllır. }\end{array}$ & $\begin{array}{l}\text { Avustralya: Mütercimler ve Tercümanlar Ulusal } \\
\text { Akreditasyon Kurumu (NAATI) }\end{array}$ \\
\hline
\end{tabular}

Tablo 1: Çevirilerin resmi geçerlilik kazanması konusunda farklı ülkelerde gerçekleştirilen uygulamalar

\section{6. Ülkemizdeki yeminli tercümanlı müessesesi ve farklı ülkelerdeki yeminli/tasdikli çeviri uygulamalarının değerlendirilmesi:}

Ülkemizde Noterlik Kanunu'nun ilgili maddeleri (8.kısım, 1. bölüm 6o. madde; 9. kısım, 5. bölüm, 103. madde) uyarınca bir dilden bir başka dile çevrilen ve resmi geçerlilik kazandırılması gereken belgeler ile ilgili işlemler için noterler yetkilendirilmiştir. Bu uygulamaya göre, bir yeminli çevirmen tarafından yapılan çevirinin, resmi tasdik gerektiren durumlarda, ayrıca bir de noter tarafından onaylanması gerekmektedir. Pym vd.'nin yeminli/tasdikli çeviri uygulamaları konusunda yaptıkları sınıflandırmada "yeminli çeviride noterlik uygulamasına” örnek gösterdikleri tek ülke Türkiye'dir (2012, s. 26). Ülkemizde var olan bu uygulamada yeminli çevirmen olarak görev yapacak olan kişilere karar veren de yine noterler olmaktadır. Bu kararı verirken de herhangi bir yetkinlik sınavı uygulaması yapılmamaktadır. Noterlik Kanunu Yönetmeliği’nin 96. maddesinde belirtilen evrakları sunabilen kişiler noterlerin kanaat getirmesiyle bir yemin zaptı imzalayarak yeminli çevirmenlik unvanına sahip olabilmektedir. Diğer yandan, bu unvanı elde etmiş olan çevirmenlerin yaptıkları çevirilerin resmi nitelik kazanabilmesi için tekrar çevirmenin bağlı bulunduğu noter tarafından tasdik edilmesi gerekmektedir. Diğer bir deyişle, çevirinin resmi olarak onaylanması aslında noterlerce yeminli çeviri yapmak üzere yetkilendirilmiş çevirmen tarafından değil, yine bizzat noterin kendisi tarafından yapılmaktadır. 
Certified translations: A general overview on sworn translation in Turkey and sworn/ certified translation procedures around the world / N. M. Uysal (pp. 709-724)

"Yeminli/onaylı/tasdikli çeviri" konusunda farklı uygulamaların bulunduğu ve bu çalışmada incelenen ülkelerin hiç birinde bu tarz bir düzenleme yer almamaktadır. Yeminli çeviri kavramının var olduğu ve kullanıldığı ülkelerden olan Almanya, Slovenya, İspanya ve Romanya'da yeminli çevirmenlerin belirlenmesi, bir devlet kurumu tarafından dil ve çeviri becerilerini ölçen sınavların ölçüt olarak kullanılması yoluyla yapılmaktadır. Bu sınavlarda başarılı olan çevirmenler yeminli çevirmen unvanına sahip olarak genellikle ülkedeki ilgili kayıt sisteminde yer alırlar. Yaptıkları çevirilerde ayrıca bir noter onayı aranmaz veya gerekli görülmez. Yalnızca Romanya örneğinde noterlerin müdahil olduğu bir süreçten bahsedilmiştir, ancak noter onayının buradaki tek işlevi çeviriyi yapan kişinin Adalet Bakanlığı'na kayıtlı bir çevirmen olduğunu doğrulamaktır ve bu onay bazı evrakların resmiyet kazanması için gerekli olmaktadır. Dolayısıyla, Pym vd.'nin (2012) gerçekleştirdiği çalışmada yer alan sekiz ülkenin hiç birinde ülkemizde gerçekleştirilen yeminli çeviri uygulamasına benzer bir uygulamaya rastlanmamaktadır. Bu ülkelerde yeminli/tasdikli çeviri yapacak çevirmenler bu yetkiyi genellikle dil ve çeviri becerilerini ölçen bir sınav sonucunda elde etmektedir. Bu sınavlar da Adalet Bakanlığı veya Dış İşleri Bakanlığı gibi bir devlet kurumu ya da çeviri ile ilgili mesleki faaliyetleri düzenleyen ve çevirmenleri temsil eden bir meslek örgütü, dernek, federasyon vb. tarafından gerçekleştirilmektedir.

Ülkemizde yeminli çeviri ve noterlik ile ilgili uygulamalar aslında çeviri ihtiyacının çok az olduğu ve noterlerin tercümanlar ile aynı çatı altında çalıştıkları 1970'li yıllara dayanan kanun maddelerine göre sürdürülmektedir halen. 90'lı yllardan sonra artan çeviri hacmi ve sektörün büyümeye başlamasıyla beraber Noterler Birliği çeşitli genelgeler yayınlayarak zaman içinde gelişen ve değişen ihtiyaçlara göre düzenlemeler yapmaya çalışmıştır, fakat bu genelgeler de kapsamları gereği kanunda yer almayan bazı durumlarda yapılabileceklere yönelik olarak hazırlanmıştır. Yeminli çeviride noterlik uygulaması ülkemizde çevirmenlik mesleğinin gelişimi ve saygınlı̆̆ açısından oldukça olumsuz bir tablo oluşturmaktadır ve bu olumsuzlukların giderilmesi gerekmektedir. TÜÇED Başkanı Ahmet Varol'un da belirttiği gibi, noterler T.C. vatandaşı olup dil bildiğini belgeleyebilen herkese aslında noterlerde maaşlı olarak çalışan çevirmenlere/memurlara yapılması maksadıyla düzenlenmiş olan yemin zaptını yaptırabilir. Ve bu zapta sahip olan her birey yeminli çevirmen olarak çeviri sektöründe kendine yer bulabilir (Varol, A. , kişisel görüşme, 28 Kasım 2019). Burada önemli olan nokta ve belki de mesleğin önündeki en önemli tehlikelerden biri toplumda zaten yaygın olan "dil bilen herkes çeviri yapabilir" düşüncesini destekleyen bir uygulamanın kanunlar çerçevesinde resmen yapıllyor oluşudur. "Yemin zaptı, özelde ve resmiyette çevirmenin yetkinliğinin bir göstergesi sayılarak dil bileni kanunlar karşısında ve toplum nezdinde legalleştirmektedir” (Kurt, 2012, s. 56). Noterlik Kanunu Yönetmeliği’nin 96. maddesine göre, noterin, "çevirmeyi yapanın o dili veya yazıyı doğru olarak bildiğine, diplomasını veya diğer belgelerini görerek veya diğer yollarla ve hiçbir tereddüde yer kalmayacak şekilde kanaat getirmesi gerekir” (Noterlik Kanunu Yönetmeliği, 1976). Noterin bu kanaate varması için, özellikle İngilizce, Almanca, Fransızca gibi yaygın olan dillerde, genellikle diploma veya Yabancı Dil Seviye Tespit Sinavı (YDS) veya Test of English as a Foreign Language, (TOEFL-Yabancı Dil Olarak İngilizce Sinavı) gibi temelde dil becerilerini ölçmek için kullanılan sınavlardan elde edilen sonuçlar yeterli olmaktadır. Dolayısıyla, yeminli çevirmenlerin seçimi konusunda noterlerin uyguladıkları ölçütler çeviri yapmayı dil bilmekle eşdeğer tutan yaygın görüşü destekler niteliktedir. Oysaki önemli olan yemin zaptı değil, çevirmenin hem çeviri yapacağı yabancı dilde hem de anadilinde iyi bir dil hâkimiyetine ve çeviri edincine sahip olmasıdır (Varol, A. , kişisel görüşme, 28 Kasım 2019).

Yeminli çeviride noterlik uygulamasının sorun teşkil eden bir diğer tarafı yeminli çevirilerin ücretlendirilmesi ile ilgilidir. Bu ücretlendirme Harçlar Kanunu'na göre yapılmaktadır. Harçlar Kanunu'nun 135. maddesine göre 5o harf 1 satır, 20 satır 1 sayfa olarak kabul edilir ve noterlerdeki çeviri ücretlendirmeleri bu hesaplamaya göre yapılır. Çevirme işlemlerine ilişkin noterlerin tahakkuk edeceği 
ücretler için yllık bir taban fiyat belirlenir ve noterlik ücret tarifesi ismiyle Resmi Gazete'de yayınlanır. Ancak, daha önce de belirtildiği gibi, çevirme işlemleri ile ilgili Noterlik Kanunu'ndaki bölümler, 1970'lerdeki uygulamaya göre, yani noterlik bürolarında çalışan çevirmenlere göre hazırlanmıştır. O dönemde noterler çalıştırdıkları çevirmen(ler) için bu ücreti tahsil etmekteydi. Yönetmeliğin, 96. maddesi, dönem koşullarına uygun olarak noter tarafından ilgilisinden alınan çevirme ücretlerinin noterlik dairesinin gelirlerinden sayıldığını ve yevmiye defterine gelir olarak kaydedileceğini belirtir (Noterlik Kanunu Yönetmeliği, 1976). Günümüzde çevirmenler noterlerde maaşlı olarak çalışmamakta, bağlı bulundukları çeviri büroları aracılığıyla veya noterlerle bağlantılı olarak serbest çevirmen statüsünde yeminli çeviri yapmaktadır. Bu sebeple, günümüz koşullarında noterlerin çeviri hizmeti veriyor olduğunu söylemek yanlış olur. Noterlerde "çevirme işlemi" ismiyle sunulan hizmet, "çeviri büroları veya çevirmenler tarafından yapılmış çevirilerin fotokopilerinin çekilmesi ve burada yevmiye numaraları verecek şekle getirilerek tasdik edilmesidir" (BİGB, 2015, s.31). "O halde, noterler aldıkları çeviri ücretini niçin çevirmene iade etmemektedirler, hatta niçin almaktadırlar? Noter çeviri yapmadığına göre niçin çeviri ücreti alsın?” (Kurt, 2012, s. 56). Bu durumda noterin yeminli tercüman olarak birlikte çalıştı̆̆ çevirmenlere çevirme işlemleri için ödeme yapması gerekmektedir. Zaten yönetmeliğin aynı maddesinde noterin çevirmene ödediği paranın da dairenin giderlerinden olduğu yazmaktadır. Bu ifadeden 70 'li yıllarda noterlerin bu çevirme ücretini bürolarında çalışan çevirmenlere tahsis ettiği anlaşllıyor. Ancak günümüz koşullarında bu çevirme ücretlerinin çevirmenlere ödenmesi konusunda ortak bir uygulama yapılmadığı görülüyor. Aslında tamamen çevirmene ait olarak tahsil edilen çeviri ücreti konusunda noterlerin çevirmenlerle pazarlığa girebildikleri, bu sebeple de çevirmenlerin emeklerinin karşılığını almakta zorlandıkları ve notere bağımlı çalışma zorunluluğunun kaldırılmasını istedikleri ifade edilmektedir (BİGB, 2015, s.31). TÜÇED Başkanı Ahmet Varol, noterlerin bu çevirme ücretini çevirmenlere ödemediklerine dair derneklerine şikâyetler geldiğini belirtmiştir. Gelen şikâyetlere göre bazı noterler çevirmenlere hiç ödeme yapmamakta, bazıları müşteriden tahsil edilen ücretin \%50'sini, bazıları ise tamamını çevirmene ödemektedir (Varol, A. , kişisel görüşme, 28 Kasım 2019). Dolayısıyla, çevirmenlerin yaptıkları çeviriler için elde edecekleri kazanç çevirmen ile noterin yemin zaptı oluşturulurken yapmış olduğu anlaşmaya ve birlikte çalışılan noterin kanaatine bağlıdır. Noterler Birliği’nin 21.01.2010 Tarihli 7 Sayılı Genelge'yi çıkarmasında bu konuda yaşanan sıkıntıların etkili olduğu düşünülebilir. Bu genelgeye göre, çevirme işlemlerinde noterlerce müşteriden talep edilen çevirme ücretinin yarısının tercümana ödenmesi gerekmekteydi. Fakat genelge 2016 yllında yürürlükten kaldırılmıştır. Bugün çevirme ücretinin çevirmene ödenmesi konusunda piyasada bir belirsizlik hâkimdir. TÜÇED ve TURÇEF gibi çevirmen örgütleri çevirmenlerin aleyhine işleyen bu ücretlendirme konusunda değişiklikler yapılmasına yönelik çalışmalar yapmaktadır.

\section{Sonuç ve tartışma}

Bir çeviri evraka resmiyet kazandırılması yeminli/tasdikli çeviri olarak adlandırılan çeviri alanını oluşturmaktadır. Yeminli/tasdikli çeviride çevirmenin bir kurum/mercii tarafından yetkilendirilmiş olması beklenir. Ülkemizde ve dünyanın çeşitli ülkelerindeki uygulamalar incelendiğinde, bu yetkilendirme işleminin birkaç farklı usul ile yapılabildiği görülmektedir. Yaygın olarak uygulanan yetkilendirme prosedüründe bir devlet kurumu veya meslek örgütü istenilen şartları sağlayan ve başarı ölçütü olarak kullanılan bir sınavda yeterli performansı göstermiş olan adaylara "yeminli/sertifikalı çevirmen" unvanını verir ve yeminli çeviriler bu çevirmenler tarafından yapılır. Bu makalede sıklıkla değinilen "Çeviri ve Çok dillilik: Çevirmenlik Mesleğinin Avrupa Birliği’ndeki Durumu” isimli araştırma raporunda yer alan ülkelerden Almanya, Slovenya, İspanya ve Romanya yetkilendirmenin bir devlet kurumu tarafından yapıldığı, Amerika, İngiltere, Kanada ve Avustralya ise yetkilendirmenin bir meslek örgütü tarafından yapıldı̆̆ı ülkelere örnek gösterilebilir. Bu kategorideki çevirmenler çevirdikleri bir 
Certified translations: A general overview on sworn translation in Turkey and sworn/ certified translation procedures around the world / N. M. Uysal (pp. 709-724)

metni mühür, imza vb. yollarla onayladıklarında genellikle yaptıkları çevirinin doğru ve güvenilir olduğunu onaylamış olurlar. Diğer yandan, yukarıda ismi geçen araştırma raporunda ele alınan ülkelerin hiçbirinde örneği görülmemekle birlikte, bu yetkilendirmenin noter vasıtasıyla da olabildiğinden bahsedilmiş ve ilgili raporda yalnızca Türkiye bu yetkilendirme türüne örnek gösterilmiştir. Ülkemizdeki yeminli çeviri ve noterlik uygulamasında, çeviriye resmiyet kazandırılması gereken pek çok durumda yeminli çevirmenin onayı yeterli olmaz, evrakın bir de noter tarafından onaylanması gerekir.

Ülkemizde bugün, yeminli çeviri ve noterlik ile ilgili uygulamalar aslında çeviri ihtiyacının çok az olduğu ve noterlerin tercümanlar ile aynı çatı altında çalıştıkları 1970'li yıllara dayanan Noterlik Kanunu ve Noterlik Kanunu Yönetmeliği’ndeki hükümlere göre sürdürülmektedir. Bu uygulamanın hem yeminli çevirmenler hem de çevirmenlik mesleği açısından olumsuzluk teşkil eden yönleri bulunmaktadır. Bu olumsuzluklardan biri yetkilendirme usulüdür. Noterler tarafından gerçekleştirilen yeminli çeviri sürecinde, noter yalnızca yabancı dil belgesi veya diplomaya bakarak, çeviri edincine yönelik herhangi bir yetkinlik kriteri olmaksızın, adayın yeminli çeviri yapabileceğine kanaat getirir ve bir yemin zaptı düzenler. Böylelikle aday yeminli tercüman unvanını elde eder. Fakat çevirinin resmiyet kazanması için genellikle çevirmenin çevirdiği belgelerin tekrar aynı noter tarafından onaylanması gerekir. Diğer bir deyişle, bu sistemde evrakın resmileştirilmesini sağlayan mercii bu iş için yetkilendirilen çevirmenden ziyade noterdir. Bir diğer olumsuzluk çevirme ücretlerinin çevirmenlere ödenmesi konusunda yaşanmaktadır. Noterler çeviri büroları veya çevirmenler tarafından yapılmış çevirilerin tasdiki için çevirme işlemi adı altında ücret almakta ve çeviri ücreti olarak tahsis edilen bu ücretlerin çevirmenlere ödenmesi konusunda sektörde farklı uygulamalar yapılmaktadır ve çevirmenler çalışmalarının karşıllı̆ını almakta zorlanabilmektedir.

Özetle, ülkemizdeki yeminli çeviri faaliyetlerinin, bugün halen 1970'li yıllardaki koşullara göre düzenlenmiş olan Noterlik Kanunu ve Noterlik Kanunu Yönetmeliğindeki hükümlere bağlı olarak yürütülüyor olmasının yeminli çevirmenler ve çevirmenlik mesleği açısından yanlış bir uygulama olduğu söylenebilir. Bu uygulamanın değiştirilmesi ve yeminli çeviri alanının daha sağlıklı işleyen bir çalışma alanı olabilmesi için bu konuda atılabilecek adımları, çeşitli önerilere yer veren geçmiş çalışmalardaki fikirlere de değinerek, aşă̆ıdaki şekilde sıralayabiliriz.

1. Ülkemizde yeminli tercümanlı konusunda yetkilendirme mekanizması noterlerdir ve noterler yeminli çeviri yapacak kişilerin seçiminde kişinin dil bildiğini gösteren bir diploma ya da eşdeğer bir belgeyi kriter olarak kullanmakta ve bu belgeler doğrultusunda çevirmenlere yemin zaptı düzenlenmektedir. Yaygın olmayan dillerde ise sertifika gibi belgeler yeterli görülebilmekte, noterin kanaat kullanarak da yemin zaptı yaptırabildiği durumlar olabilmektedir (Varol, A. , kişisel görüşme, 28 Kasım 2019). "Noterlerin önlerine gelen her çeviri dilini bilmesi ve anlaması beklenemez. Doğruluğun, güvenirliğin sağlandığı bir müessesede doğruluğundan emin olunmayan yazıyı onaylamak kadar yanlış bir iş olamaz. Zira çeviriyi diploma değil, diplomanın sahibi yapmaktadır” (Kurt, 2012, s. 58). Dil belgesi veya diploma gibi belgelerin bir kriter olarak kullanılmasının sebeplerinden biri belki de ülkemizde bir bireyin kaliteli, yeterli ve verimli çeviri yapma yeteneği veya birikimine sahip olup olmadığını test eden bir sertifika ya da belgelendirme sisteminin bulunmayışıdır (Uysal vd., 2015, s. 262). Bu konudaki eksiklik giderildiğinde yeminli çeviri alanında çalışan çevirmenler de belgelendirme sistemi çerçevesinde değerlendirilebilir ve yalnızca uygun sertifikaya sahip olan kişilerin yeminli çeviri yapması sağlanabilir. Örneğin, hukuk ve finans metinleri ve resmi belgelerin çevirilerinde dikkat edilmesi gereken hususlar konusunda eğitim faaliyetleri düzenlenebilir ve adayların bu konulardaki hâkimiyetleri ölçülebilir (Dragoman, 2015). 
2. Mevcut sistem içerisinde noterler tasdik işlemlerinde çeviri evraklardan harç ve diğer giderlerin yanı sıra bir de çevirme ücreti almaktadırlar. Bu ücretin noterlik makbuzundan çıkarılması ve direk çevirmenlere fatura karşılı̆̆ı ödeme yapılmasının sağlanması gerekmektedir (Erbil, 2012, s. 14; Kurt, 2012, s. 58)

3. Çevirmenlik mesleği açısından bakıldığında, asıl yapılması gereken "noter özel ve tüzel kişiliği makamına şahsi tercümanlık" müessesesinin tamamen ortadan kaldırılması ve noterlere yemin zaptı yaptırılmamasıdır. Noterlerde sadece yabancıların vekâlet verme gibi işlemlerinde çevirmen kullanılmalı ve bu durumda da ancak meslek sicil numaralı çevirmenlerin imzaları geçerli olmalı ve çeviri ücreti fatura karşllı̆̆ında direkt olarak çevirmene ödenmelidir (Erbil, 2012, s. 14-15).

4. Yeminli çeviri ve yeminli çevirmenlik konusunda yeni bir mekanizma kurulmalıdır. Resmi belgeler meslek sicil numaralı çevirmenler tarafından çevrilip, noterler yerine yeminli çevirmenlerin kendileri tarafından veya mesleki sicil numaralı çeviri işletmeleri tarafından tasdik edilebilir (Altay \& Ateşman, 2012, s. 3; Erbil, 2012, s. 14). Bunun yanı sıra, çevirmenlerin meslek odası, birlik veya federasyon gibi oluşumlarla kendi denetim mekanizmalarını kurmaları sağlanmalı ve çevirmenlik yasası çıkarılmalıdır. Yeminli çevirmenlerin yetkilendirilmesi ve denetlenmesi hususunda bu meslek odası, birlik veya federasyonun söz sahibi olması gerekir.

\section{Kaynakça}

2020 Yllı Noterlik ücret tarifesi (t.y.). Erişim adresi

https://portal.tnb.org.tr/Tebligler/Noterlik\%20\%C3\%9Ccret\%20Tarifesi.pdf

Altay, A., Ateşman, E. (2012). Ulusal Çeviri Politikasına Doğru. Avrupa Birliği Bakanlı̆̆ Çeviri Platformu Bildirileri. İstanbul. https://www.ab.gov.tr/files/ceb/Ceviri_Platformu_Resimleri/platform_bildirileri.pdf

Dragoman. (20 Temmuz 2015). Yeminli çeviri ilkeleri. [Blog yazısı] Erişim adresi https://www.dragoman.ist/tr/yeminli-ceviri-ilkeleri/

Erbil, S. (2012).Uygulamalı Çevirmenlik Eğitim Formasyon Projesi Önerisi. Avrupa Birliği Bakanlı̆̆ Çeviri Platformu Bildirileri. İstanbul. Erişim adresi https://www.ab.gov.tr/files/ceb/Ceviri_Platformu_Resimleri/platform_bildirileri.pdf

Ersoy, H., Odacıŏlu, C. (2014). Türkiye'de serbest çevirmenlerin karşılaştıkları sorunlar, bu sorunların etkileri ve öneriler. Turkish Studies-International Periodical for the Languages, Literature and History of Turkish and Turkic. 9(6), 367-378.

Kartal, K. (2012). Çeviri sektörü: Sorunlar ve çözüm önerileri. Avrupa Birliği Bakanlı̆̆ Çeviri Platformu Bildirileri. İstanbul. $\quad$ Erişim adresi https://www.ab.gov.tr/files/ceb/Ceviri_Platformu_Resimleri/platform_bildirileri.pdf

Kobya, Senem and Karabacak, Funda, ed. (2015). Çeviri Kitabı. İstanbul: Universal. Erişim adresi https://www.cevirikitabi.com/cevirmenler-ne-isler-ceviriyor/turk-ceviri-sektoru-kimlik-karti/

Kurt, M. (2012). Çeviri ve çevirmenlik mesleğinin Hukuk Muhakemeleri Kanunu ve Ceza Muhakemesi Kanunu’ndaki yeri. Avrupa Birliği Bakanlı̆̆ Çeviri Platformu Bildirileri, İstanbul. Erişim adresi https://www.ab.gov.tr/files/ceb/Ceviri_Platformu_Resimleri/platform_bildirileri.pdf

Noterlik Kanunu Yönetmeliği. (13 Temmuz 1976). Erişim adresi https://www.mevzuat.gov.tr/Metin.Aspx?MevzuatKod=7.5.5040\&MevzuatIliski=o\&sourceXml Search

Noterlik Kanunu. (18 Ocak 1972). $\quad$ Erişim https://www.mevzuat.gov.tr/MevzuatMetin/1.5.1512.pdf 
Certified translations: A general overview on sworn translation in Turkey and sworn/ certified translation procedures around the world / N. M. Uysal (pp. 709-724)

Odacıoğlu, M.C., Barut, E., Odacıoğlu, F.Ç. (2018). Kamuda çalışan mütercim tercümanların yaşadıkları temel sorunlar ve bu sorunlara karşı çözüm önerileri: Türkiye örneği. Uluslararası Sosyal Araştırmalar Dergisi. 11(58), 155-165.

Pym, A., Grin, F., Sfreddo, C., Chan A.L.J. (2012). Studies on translation and multilingualism. The status of the translation profession in the European Union. European Commission. Erişim adresi, https://termcoord.eu/wpcontent/uploads/2013/o8/The_status_of_the_translation_profession_in_the_European_Uni on.pdf

Seymen, G. D.; Selcen Aslan, A. (2019). Türkiye'de çevirinin toplumsal görünürlüğü ve gelişiminde çeviri derneklerinin rolü. RumeliDE Dil ve Edebiyat Araşttrmaları Dergisi, (15), 377- 390. DOI: $10.29000 /$ rumelide.580650

T.C. Başbakanlık İdareyi Geliştirme Başkanlı̆̆ı. (2015). Türkiye’de Çevirmenlik Mesleği. Erişim adresi,http://www.konsolostercume.com/Turkiyede\%2oCevirmenlik\%2oMeslegi\%20\%20Arastirma\%2oRaporu.pdf

TURÇEF Yeminli Çevirmenlik Federasyonu. (t.y.) TURÇEF ÜYESİ Çevirmen ve Çeviri Bürolarmmn dikkatine!. Erişim adresi, https://www.turcef.net/turcef-uyesi-cevirmen-ve-ceviri-burolarinindikkatine

Türkiye Çevirmenler Derneği. (t.y.). Noter ile ilgili meslektaşlara duyuru. Erişim adresi http://www.tuced.org.tr/

Uysal, N.M. (2017). Çevirmenlikte Meslekleşme ve Çevirmen Sertifikasyonu. Ankara: Gece Kitaplığı.

Uysal, N.M., Odacıŏglu, M.C., Köktürk, Ş. (2015). Meslekleşme açısından Türkiye'de çevirmenliğin mevcut durumu, sorunlar ve çözüm önerileri. Uluslar arası Sosyal Araştırmalar Dergisi, 8(36), 257-266.

Yener, Y. (2004). Çeviri bürolarında çeviri ve çevirmenlik. (Yüksek lisans tezi). İstanbul Üniversitesi, Sosyal Bilimler Enstitüsü, Çeviribilim Dalı. Erişim adresi https://tez.yok.gov.tr/UlusalTezMerkezi/tezSorguSonucYeni.jsp 